\title{
A alma de Guesa em ação
}

Cilaine Alves Cunha Universidade de São Paulo

Resumo: Em algumas passagens, O Guesa recorre ao sistema de verossimilhança neoclássico, ajustando a ação do protagonista pelo dever ser dos bons costumes e da decência. O poema mobiliza ainda o verossímil privilegiado no século XIX, introduzindo verdades particulares que se distanciam da convenção em curso. $O$ autor também se vale da máxima segundo a qual a conduta das personagens pode ser regulada por uma radical originalidade.

Palavras-chave: Verossimilhança, Convenção, Originalidade.

motivo da errância modela O Guesa, de Sousândrade, que o constitui como narração da viagem imaginária do herói por diferentes países e períodos históricos da América, África e Europa. A abertura reproduz passagens da enciclopédia L'Univers e de Vue des Cordillières, de Humboldt, recontando uma suposta lenda dos antigos indígenas da Colômbia, os muíscas. Por ela, o Guesa, criança errante e sem lar, é arrancado de seus pais ao nascer, a fim de ser sacrificado a Bochica, deus do sol. Em seguida, o jovem sofre um período de dez anos de preparação e peregrina por mais cinco anos até o caminho do Suna, mesma travessia que a divindade teria antes percorrido.

Apropriando-se da lenda, o poema relata a vida de Guesa que, saindo dos Andes e da mitologia indígena pré-colombiana, caminha pelo período anterior 
à chegada de Colombo, desloca-se em seguida pela história da América e do Brasil, atravessando a colonização, a invasão portuguesa, a Independência, a monarquia. Retornando a uma África ancestral, segue para os Estados Unidos de fins do século XIX. Enquanto isso, assiste-se aos eventos históricos que desaguaram no extermínio e degradação dos povos indígenas. Recriando o espetáculo da história pelo mito da queda, o poema canta a derrota dos vencidos.

Uma alternância de vozes entre o narrador e o protagonista narra a fábula predominantemente em monólogo. Formalmente distintas, as duas vozes assumem, porém, uma mesma posição sobre a história e as relações humanas. Além disso, Sousândrade aplica alguns aspectos de sua vida pessoal na biografia do herói, sem que realize, no entanto, uma identidade absoluta entre ele e o autor empírico. Pode-se supor que o autorretrato seja uma ficção cuja fonte origina-se na fantasia que recorta, seleciona e estabelece relações de causa e consequência entre os eventos de tal modo que tudo pode ser motivo, ou efeito. A transposição de traços da vida do autor na construção do herói pode resultar de uma operação homóloga àquela com que neste se moldam personagens arquetípicas da tradição ocidental: os heróis indígenas, Jesus Cristo, Prometeu, Ahasverus, Napoleão Bonaparte, Gonçalves Dias, os garotos aprisionados pela lendária Iara, a bela criança africana do canto VII, o Childe Harold, Byron, Guesa e o narrador amalgamam-se simbolicamente no emblema de gênios talentosos vitimados pela perfídia humana, ou dos heróis sacrificados pela humanidade que, nessa missão, viram traída a sua inocência juvenil.

O ponto de união entre essas figuras reside no lugar comum da juventude que espera por uma "ação livre e social virtude". A revolta juvenil contra as instituições políticas dirige a sua afetividade aos países e povos marginalizados pelas nações imperialistas, encarnando uma suposta candura natural decaída pelo egoísmo e pelas práticas mercantis. O Guesa "reveste-se do signo" da tradição ocidental, ganhando uma fisionomia etérea e fantasmática que erra por mundos e tempos afora, movido pela convicção de que "antes da gratidão da família, / existe a ardente pátria probidade”.

Ao compor a linha conflituosa da história pelo mito da queda, Sousândrade recorre a Victor Hugo e organiza seus temas pela antítese, forjando os polos europeu / americano, colonizador / colonizado, monarquia / república,

1. Cf. LOBO. Épica e modernidade em Sousândrade, p. 46. 
capitalismo mercantil / capitalismo industrial, cidade / campo e corrupção / inocência. Esse conflito responsabiliza paradoxalmente a colonização, o regime monárquico, D. Pedro II, a parcela corrupta do clero e o capitalismo mercantil pela destruição dos antigos costumes rurais e patriarcais, pela degradação da instituição familiar, de comunidades indígenas e pela alienação das tradições nacionais. Nos termos do outro extremo, a herança de Rousseau desemboca na politização do tópico do campo e na substituição do emblema do pastor pelo lavrador desprotegido. ${ }^{2}$ A cidade liga-se convencionalmente à cobiça, à devassidão e à usura, mas também à acumulação primitiva, à fome e à exclusão social. Esse conflito deságua na perda das qualidades ético-morais da vida campestre e na traição dos ideais de libertação dos povos. Apoiando-se na república de Platão e na idealização do império inca, ${ }^{3}$ Sousândrade espera por uma política que eduque as elites econômicas para o amor à humanidade e integre e conceda aos índios os direitos políticos da nação democrática, republicana, liberal e cristã. Guesa tem "pressa de futuro e de ciência" e de um paradoxal capitalismo humanitário, fraterno e cristão.

À encenação da história americana justapõem-se, no entanto, outros temas, configurando o poema como um excesso. A narração da fábula entrecruzase a imagens diáfanas sobre as regiões do mundo visitadas ou evocadas. A recriação de algum mito indígena, grego, romano, bíblico ou alguma lenda do folclore popular alterna-se com os "abismos internos" que tudo isso mobiliza no Guesa-poeta. O poema expõe ainda reflexões sobre a cultura ameríndia e a do país; sobre os pressupostos estéticos do próprio poema, as convenções artísticas do século XIX e sobre seus autores queridos da tradição.

Essa tessitura adia constantemente a apresentação das experiências de Guesa e joga, para um mesmo plano de importância, as digressões líricas e as reflexões do narrador, com seus "turbilhões de cismares filosóficos, de paixões tumultuosas, de melancolias plangentes, de ironias amargas". ${ }^{4}$ A abordagem de tantos assuntos gera ainda o misto de crônica de viagem e histórica, mininarrativas de autorrevelação, expressão do sentimento e conflitos interiores, reflexão históricosocial e, com isso, a junção de gêneros e estilos.

2. Cf. AuerbaCH. Mimesis, p. 438-439.

3. Cf. CAMPOS. Estilística sousandradina (aspectos macroestéticos). In: Revisão de Sousândrade, p. 48. CUCCAGNA. A visão do ameríndio na obra de Sousândrade, p. 96-101.

4. PEREIRA DA SILVA, citado em SOUSÂNDRADE. Memorabilia. In: Poesia e prosa reunidas, p. 488. 
A passagem de um tema para outro pode, às vezes, prescindir de informações que a indiquem ou se realizar rapidamente. A quebra da linearidade temporal forja uma cronologia que, vindo e indo, entronca no presente o passado e o porvir, concentrando épocas distantes em um mesmo espaço. Alguns grupos de imagens jorram, com relativa autonomia, um fluxo digressivo de consciência. Às vezes o narrador suspende a exposição de uma reflexão ou a composição de uma imagem ou cena, apenas iniciadas, para completá-las só mais adiante. No intervalo, interpõe uma metáfora extremamente fechada. Outras imagens que contextualizam a fábula no espaço e no tempo dissolvem-se em visões etéreas. Radicalizando a defesa romântica da liberdade do "gênio," Sousândrade joga com aglutinações de vocábulos, neologismos, abreviações, anagramas, arcaísmos, hibridismos idiomáticos e colagens de manchetes de jornal.

Ao lado de sua ousadia formal, o aproveitamento da mitologia dos povos indígenas pré-colombianos e amazônicos, desconhecidos do sistema cultural brasileiro, e a publicação das duas edições originais em Nova York e em Londres podem ter dificultado a recepção do poema em meio ao grande público. Com a Revisão de Sousândrade, em 1964, Augusto e Haroldo de Campos favoreceram a circulação do poema no circuito acadêmico. À reunião de alguns cantos de $O$ Guesa e de poemas de outras obras do autor os organizadores acrescentaram excelentes análises do sistema poético sousandradino, com descrições minuciosas de seus procedimentos estilísticos fundamentais. Ao esclarecer fontes, modelos e mitos das culturas incaicas e amazônicas, os Campos muito contribuíram para o desenvolvimento de pesquisas sobre a obra do autor.

Até então, as histórias da literatura ou silenciavam ou lhe dedicavam um curto espaço, avaliando-o como desnivelado, desequilibrado, "espasmodicamente prolixo", ora mesmo situando-o entre os extremos da "inspiração e da aberração". Revisão de Sousândrade inverteu os polos de aferição do poema. Desde então, a subversão da linguagem e a estrutura aparentemente desconcertante tornaram-se exceção no tempo romântico, abrindo espaço para leituras que definem Sousândrade como parnasiano, realista, pré-simbolista, "antecipador" das vanguardas estéticas do século XX e "pós-modernista", sem deixar de confundi-lo com a figura do indomável gênio titânico.

5. Cf. CAMPOS. Estilística sousandradina (aspectos macroestéticos). In: Revisão de Sousândrade, p. 89-120. 
Em alguns aspectos, o poema antecipa as "vanguardas modernistas" na medida em que, para falar com Isaiah Berlin, ${ }^{6}$ o romantismo implementou uma revolução poucas vezes precedente que se alastrou também pelo terreno da cultura, abalando as bases do sistema ético do Antigo Regime. Ao prescrever códigos éticos e estéticos antes imprevistos, condensou, durante a sua vigência, as inovações que vieram se expandindo e radicalizando-se desde então.

Para dar corpo ao discurso narrativo de O Guesa, Sousândrade recorre a processos de verossimilhança previstos no século XIX. Algumas passagens do poema regulam a consciência e a ação do Guesa-poeta pelo corpo de máximas aceitas como verdadeiras em seu tempo, ajustando-as ao dever ser dos bons costumes e da decência. ${ }^{7}$ No canto IV, o herói retorna ao Maranhão, sua terra natal, e reencontra antigos amores. Antes de encenar a prática sexual entre Virjanura e o herói, o narrador discute duas condutas femininas distintas, representadas pela recatada esposa e pela virtuosa donzela, de um lado, e pela "nubente depravada", de outro, cuja prostituição associa-se aos "crimes das trevas" e à promiscuidade da vida urbana. Ao contrapor-lhe o dever ser da "formosa desposada", o narrador ecoa a convenção do tempo que prescreve que a decência feminina restringe-se aos limites do casamento. A dignidade da mulher afere-se por sua disposição para se tornar mãe de seu marido e irmã da parentalha. ${ }^{8}$ Nesses momentos de maior fidelidade de O Guesa ao verossímil neoclássico, o narrador adapta a postura discursiva do Dirceu de Tomás Antônio Gonzaga ensinando códigos de sociabilidade a sua Marília, quando procura persuadir o leitor a respeito dos princípios que levam Guesa a se curvar "com a religião da infância do homem/ À virtude, à belleza, à dor."”

Na composição de Virjanura, o poeta apropria-se do misticismo com que o romantismo envolveu a virgem encantada, constituindo-a como "divina aparição", "maga donzella" e "branca estatua da grande formosura". Guardando semelhanças com a Mignon de Goethe, Virjanura (virgem natura?) funde-se a imagens da terra natal que "n'alma se alevantam", tornando-se emblemática de

6. BERLIN. Estudos sobre a humanidade. Uma antologia de ensaios, p. 559.

7. Para essa discussão sobre os graus de verossimilhança em Sousândrade, valho-me de GENETTE. Vraisemblance et motivation. In: Figures II, p. $71-100$.

8. SOUSÂNDRADE. O Guesa, canto IV, p. 92-93.

9. SOUSÂNDRADE. O Guesa, canto IV, p. 85. 
uma paradisíaca nação americana primeva, aquém da história, quando reinaria um tipo de organização humana desprovida de conflito moral e social.

Ao relatar, no entanto, a concretização do ato sexual entre as personagens, Sousândrade viola a virgem encantada. Para tanto, conta com outro verossímil privilegiado no século XIX que, enquanto introduz verdades particulares que contradizem ou distanciam-se da convenção ética e estética em curso, fornece explicações e comentários que justifiquem o distanciamento. O relato do ato sexual alterna narração e comentários em defesa da profanação do eterno feminino, acusando, com Álvares de Azevedo, Bernardo Guimarães e outros, um estupor com a lira amorosa idealista. Num momento em que a lâmpada da utopia já se apagara e fizera germinar as mágoas do coração," "a paixão cansa; do ideal a sede / Jamais saciada, cansa”." Reproduzindo a discussão do tempo acerca do esgotamento da lira amorosa com seus excessos idealistas, Sousândrade leva seu herói a apropriar-se de sua amada para que o autor possa também revisar e macular as convenções do gênero.

Considerando, no entanto, que a dignidade feminina reside na "desposada", o poeta, antes da figuração do ato sexual, adulou o decoro vigente, traçando estratégias para conquistar a cumplicidade da opinião pública com a máxima romântica que propôs, desde o romance Lucinde, de Schlegel, e a Gretchen, de Fausto, que uma moça que se entrega ao amante, fora do contrato conjugal, pode se manter heroica. Para não ferir por completo a suscetibilidade de seu público, as ressalvas que reafirmam idealmente a decência e a modéstia da suposta esposa acolhedora antecederam o relato da consumação sexual. No mesmo intuito de explicitar princípios que justifiquem o ato de Guesa de retirar os véus de sua musa, o narrador recorre às máximas da sexualidade masculina de seu tempo quando alega como necessidade a plenitude do êxtase do herói. Para não cair no abismo, Guesa se sustém nos prazeres proporcionados pela amante, nela se reconfortando das angústias da vida. ${ }^{12}$ Mesmo que contrarie as regras da conduta feminina, Virjanura, com essas racionalizações, pode se entregar ao amante e, assim, preservar a integridade moral e a idealidade que a cerca.

10. SOUSÂNDRADE. O Guesa, canto IV, p. 100.

11. SOUSÂNDRADE. O Guesa, canto IV, p. 96.

12. SOUSÂNDRADE. O Guesa, canto IV, p. 99. 
Em um terceiro processo de verossimilhança, outras passagens de $O$ Guesa negam fidelidade ao código de máximas e preconceitos tidos por verdadeiros em seu tempo, emudecendo-se quanto aos motivos que regem a ação de suas personagens. O autor recorre então a outro procedimento recorrente no século XIX segundo o qual a conduta das personagens pode ser regulada pela "verdade particular de uma imaginação profunda”. 13 Para produzir a sua originalidade, um romântico pode apoiar-se no princípio de que a arte é demiurgia, campo privilegiado de acesso ao mistério das coisas e do Universo. Nesse caso, assume a arbitrariedade das motivações da ação de seu herói, recusando-se a fornecer-lhes os referentes para a sua legibilidade. Nesses momentos, a referenciação do poema encontra-se depositada na vida interior do poeta, o que liga o universo da criação ao imaginário fechado do autor que, assim, gera incomunicabilidade e bloqueia a recepção.

Em O Guesa, a reposição de preceitos setecentistas pode ser observada na preservação residual da mitologia clássica e na natureza do engajamento edificante do poema, também perpetuadas, em cada um deles de modo mais, menos ou nada libertário, por Gonçalves Dias, José de Alencar, Castro Alves, entre outros. Estes autores postulam a autonomia e a especialização da arte e destinam, paradoxalmente, à sua obra a tarefa de apregoar a fé em Deus, na razão, no progresso e na ciência. Em Gonçalves Dias, a defesa destes princípios e o esforço para corrigir os costumes e fornecer regras de sociabilidade ao recente país independente somam-se ao seu abolicionismo favorável ao regime monárquico. Em Alencar, o caráter utilitário de sua obra põe-se também a serviço da compreensão de que a escravidão e o imperialismo sejam natureza, e o fluxo da história destino inelutável. No entanto, no mesmo decênio em que Gonçalves Dias se impusera como o poeta de maior expressão nacional, a racionalidade científica, o progresso e Deus sofriam seus primeiros abalos no devaneio de céticos como Bernardo Guimarães e Álvares de Azevedo. Diante disso, a unidade prevista no termo "romantismo" desmorona-se.

O périplo de Guesa é também metáfora, como já foi dito, da própria obra, concebida como uma engajada experiência em favor do regime republicano, do liberalismo e do abolicionismo. Destinando ao narrador e à sua obra essa função utilitária, ele a perpetua como apostolado. Ao se tomar como carne do mandamento cristão, dos princípios iluministas, republicanos e abolicionistas, vazando-os ora

13. GENETTE. Vraisemblance et motivation. In: Figures II, p. 79. 
numa conversação íntima consigo, ora dramaticamente, o narrador de O Guesa abre mão nos dois casos de estilizar um leitor hipotético que replique as suas convicções. Para a sua modernidade estética, e ainda que em outros aspectos o seja, O Guesa não pretende relativizar a sua verdade, como se observa em outros autores do período em que o dialogismo irônico é norma. Pouco intensifica a profundidade psicológica da consciência narrada, limitando-a ao maniqueísmo dos polos vício e virtude, crença e dúvida, monarquia e república, inocência e corrupção, liberdade criativa e heteronomia da arte etc., já previamente julgados e eleitos pela voz do autor, do narrador e do herói que partilham os mesmos princípios. Não sem contradição, O Guesa aborda certa decepção com a domesticação da natureza pela técnica, mas sempre lamenta as trevas, clamando por Luz ao longo do poema. Nesse aspecto, afasta-se do irracionalismo romântico que reagiu contra o domínio da ciência e a tecnocracia. Ainda que perscrute a força da vida interior da personagem sobre suas ações, não se furta a recorrer à doutrina cristã e ao moralismo vigente para figurar as suas motivações, reações e relações, situando-se de modo problemático no interior do processo de secularização. Sousândrade também se distancia da reação modernista contra o racionalismo, bem como de sua apologia da magia e das forças do inconsciente. A recuperação da mitologia e da lenda não se realiza, em o Guesa, como defesa de uma existência menos racionalista e como antídoto contra a alienação e o controle da vida pelo capital. No plano artístico, seu misticismo se concretiza como reivindicação de um valor de troca para a obra de arte. Na vida de uma comunidade, a valorização da lenda resulta do nacionalismo romântico que opôs a cultura letrada, tida como artificial, à poesia popular ou da "natureza", essa última associada, no romantismo brasileiro, também à fonte da cultura indígena e, no caso de Sousândrade e outros, da africana, conforme ele mesmo testemunha: ${ }^{14}$

[...] Joaquim Serra está destinado a evocar da indiferença a nossa poesia popular, esses tesouros dos sertões e das choupanas, nascidos da natureza mesma, como a voz dos seus bosques e o espontâneo gemer de suas fontes. Vamos de novo escutar as canções saudosas e rudes a que à vOZ da mãe-preta adormecíamos na infância. ${ }^{15}$

14. "Ora, o que sucedeu com a poesia popular na Europa, aconteceu no Brasil com a literatura indiana”. CHAGAS. Literatura Brasileira. José de Alencar, apud Gonçalves Dias e a crítica portuguesa no século XIX, p. 138.

15. SOUSÂNDRADE. Literatura. In: Poesia e prosa reunidas, p. 493. 
No século XIX romântico, a revolta contra as leis instituídas pela convenção ética, estética e política deriva de uma paixão pela revolução política e cultural, bem como pela razão crítica, e da compreensão de que os sistemas filosóficos são mitos que, como a literatura, procuram preencher o vazio da existência. Nadificando o sentido da vida, muitos românticos entendem que a palavra e a cultura criam o mundo, não o seu contrário. Nesse momento, o reconhecimento da lacuna entre o signo e a coisa implicou, como se sabe, a negação da participação de Deus na experiência humana. As dúvidas ou certeza quanto à legitimidade dos princípios morais e religiosos abalados pela secularização correram paralelas à compreensão de que a cultura se organiza por meio de "verdades" múltiplas, contínua e humanamente reinventadas e repostas. Já o autossacrifício simbólico e o didatismo do poeta-Guesa estilizam-se como necessidade de restaurar a suposta inocência, o amor e a harmonia que reinariam na comunidade rural pré-civilização industrial, ${ }^{16}$ bem como a suposta ordem justa e democrática, e de introduzi-los mesmo em comunidades alheias ao sistema sociocultural do Ocidente.

Ainda que recupere eventos e quadros da história, o poema sousandradino ajusta-os, com relativa ou menor clareza, à lente das impressões, sentimentos e imaginação da subjetividade narrada e narrante. Transformando-os em fantasia, sentimentos e conceitos, insere-os nos códigos morais, religiosos e políticos como um dever ser. Ao fundir os estilos neoclássico e romântico, essa mistura coloca-se a serviço de uma concepção que espera afirmar a singularidade e a originalidade autoral. Sousândrade implode a unidade, a harmonia e a clareza do enredo neoclássico, mas, preserva, em O Guesa, tópicas, temas, mitos e normas artísticas do século XVIII, filtrando-os insistentemente pelo enternecimento, contentamento, autopiedade, altíssima autoestima, frustração, indignação, sarcasmo etc. Sua capacidade de síntese da sintaxe lírica e de condensação das imagens é inversamente proporcional à abundância prolixa dos assuntos que muita vez se atropelam em livre associação.

Um dos temas de O Guesa que concorrem para afirmações que o excluem de seu tempo, seu pan-americanismo prevê um futuro ideal em que os povos indígenas brasileiros, hispano-americanos e norte-americanos se uniriam

16. "Oh! quantas azas brancas, indolentes/ N'esses grupos de amor, como se formam/ Nas varandas ruraes, nos innocentes/ Edens - que em mundo vezes se transformam!". SOUSÂNDRADE. O Guesa, canto IV, p. 90. 
fraternalmente em uma mesma unidade política. A utopia de um continente americano unificado espera redimir os ameríndios e submetê-los a uma nova cristianização supostamente legítima se comparada à ação dos jesuítas. Ainda que se reconheça que essa utopia deite suas fontes no nacionalismo romântico, sua "originalidade absoluta" derivaria da proposta sousandradina de superar, na concretização desse projeto, as particularidades culturais de cada um desses povos.

O pan-americanismo de Sousândrade reformula, no entanto, os limites do indianismo de Gonçalves Dias, restrito aos tupis, dilatando-o no espaço e no tempo, recuando-o a um tempo anterior a Colombo e até as fronteiras dos países americanos. Alguns motivos e figuras aproximam um e outro sistema indianista. Em seu singular realismo, "O canto do piaga" anuncia, pela boca de Anhangá, o gênio do mal, a matança ou a escravidão dos guerreiros tupis, bem como o sequestro de suas mulheres, levados a cabo desde a invasão europeia. Aí, as naus portuguesas metaforizam-se no arcabouço marinho que se assemelha a uma vasta selva de troncos e hastes sem folhas, deslizando sem limites pelas ondas marítimas. Em Sousândrade, velas todas-chamma, cabos de navio e mastros inflamados alegorizam a colonização e a dizimação de todos os ancestrais de Coelus, a musa equatorial do canto VIII de O Guesa.

As analogias entre os dois sistemas indianistas identificam-se ainda no canto III desse poema que, como em O Brasil e a Oceania, de Gonçalves Dias, aplica as técnicas do estilo sublime para hiperbolizar o rio Amazonas como um dos maiores e inigualáveis oceanos. Em outras passagens desse canto, a eclosão de uma tempestade no rio Amazonas empresta recursos estilísticos do poema de Gonçalves Dias, "A tempestade". ${ }^{18}$ Quer nesse canto de O Guesa ou no poema gonçalvino, a figuração da procela é antecedida pela descrição dos encantos do verão tropical, numa operação em que a justaposição destas duas forças da natureza, emblemáticas da luminosidade natural e das trevas sociais, cria um contraste entre o espetáculo arrebatador da paisagem tropical e o obscurantismo que reina no Brasil desde a invasão. Como no poema gonçalvino, a sublime providência manifesta, em O Guesa, sua ira contra os desatinos humanos, revolvendo violentamente os

17. CuCCAGNA. A visão do ameríndio na obra de Sousândrade, p. 62.

18. Por "A tempestade" refiro-me ao poema que Gonçalves Dias inseriu em meio aos Hinos de Segundos cantos (p. 251), não a seu homônimo (p. 580) recolhido postumamente no título "Lira Vária", ambos reproduzidos na Poesia completa de Gonçalves Dias. 
elementos da natureza, revolução natural esta que, por sua vez, prenuncia a suposta tendência da população a se sublevar:

Occulto o sol, simelha a Providencia

Sobre a revolução da natureza,

As massas populares na demencia

Das trevas, e uma luz na mente accesa! ${ }^{19}$

A interpretação de Sousândrade sobre a colonização guarda, no geral, pontos de semelhança com a leitura do mesmo assunto realizada por Gonçalves Dias na prosa poética Meditação (1846). Os dois sistemas indianistas supõem que o predicado negativo da colonização não está nela contido, mas resulta de seus agentes constituídos como embrutecidos, destemidos de Deus, figuras movidas pela cobiça do ouro. Na consideração sobre a escravidão, os dois poetas valem-se da tipologia cristã quando propõem que a supressão da liberdade do ameríndio prefigurou a escravidão africana. ${ }^{20}$ O Jovem espectador de Meditação, viajando imaginariamente pela história do Brasil desde os momentos mais próximos a 1500, e o Guesa, assistindo aos mesmos eventos históricos, estilizam a sua indignação diante da progressiva disseminação da escravidão pelo Brasil e mundo afora por meio da reiterada insistência no vocábulo "escravo":

E nessas cidades, vilas e aldeias, nos seus cais, praças e chafarizes

- vi somente - escravos!

E no adro ou debaixo das naves dos templos - de costas para as imagens sagradas, sem temor, como sem respeito - escravos. ${ }^{21}$

Era o rebate: escravos! mais escravos!

No bosque a liberdade estremecia,

Esplendida elevava-se e rugia,

Na luta dos villões co'os nudos bravos.

Mais escravos! E as ondas d'este rio,

Contavam-se, ai! as ondas do oceano,

Por cabeças de pallido Gentio

E por cabeças pretas de Africano!

19. SOUSÂNDRADE. O Guesa, canto III, p. 69.

20. Cf. DIAS. Meditação. Poesia completa, p. 760-762.

21. DIAS. Meditação. Poesia completa, p. 743.

22. SOUSÂNDRADE. O Guesa, canto III, p. 77. 
A obsessiva busca romântica pelas origens leva Guesa a localizar na África de tempos imemoriais a queda, em germe, da desagregação moral e social do Ocidente. Em contrapartida, retira a solução para esses problemas da suposta pureza edênica dos costumes americanos originários, antes que eles tivessem sido corrompidos pelos países dominantes. Ao procurar compreender as razões que sustentam a instituição da escravidão, Guesa traça, no canto VII, um elogio dos nobres feitos do antigo mundo africano e de sua paisagem natural, compondo, à maneira de "A escrava", de Gonçalves Dias, um hino em homenagem a sua paisagem natural e cultural. Admiravelmente e por vezes grosseiramente, o narrador de $O$ Guesa encarna na criança escrava a imagem da saudade da liberdade sequestrada. Na conclusão do canto, reforça, em metáforas encadeadas, a associação entre a "negra flor dos vales do Levante" e a "saudade crepuscular" para forjar, dessa vez de modo análogo a Castro Alves, outra alegoria. Se, no poeta de "Navio negreiro", a escravidão remonta suas causas à punição aplicada pelo patriarca Noé a Cam e seus descendentes, ${ }^{23}$ em Sousândrade a inveja fratricida de Caim contra Abel prefiguraria a desunião entre os povos e a opressão dos afrodescendentes pelos europeus. A criança-escravidão e a saudade crônica de suas vítimas derivariam do "mistério das lutas contra o mundo" e das trevas contra a Luz ditosa de Abel:

Crepuscular saudade; é o mysterio

De luctas contra o mundo; é luminosa

Vinda das trevas, d'ellas mensageiro

Innócuo, infeliz, contra a ditosa

Luz de Abel - Deus eterno! - é a vaidade,

É d'extranhos punhal: faces-amenas,

Riso evanos meigos da saudade $(\ldots)^{24}$

O pan-americanismo de Sousândrade desenvolve princípios do nacionalismo romântico que supõe, em geral, que as nações evoluiriam e expandiriam "a escalada de unidades sociais humanas, da família e da tribo para o condado e o cantão, do local para o regional, para o nacional e ocasionalmente

23. Para a compreensão de que para Castro Alves a escravidão resultou de um castigo imposto a Cam e seus descendentes pelo patriarca Noé, cf. BOSI. Sob o signo de Cam. In: Dialética da colonização, p. 246-272.

24. SOUSÂNDRADE. O Guesa, canto VII, p. 164. 
para o global". ${ }^{25}$ A propensão universalizante do pensamento sousandradino guarda fidelidade ao século XIX que, embora caminhe para impor as particularidades regionais e individuais, convive com dogmas universais. Já a valorização, em Sousândrade, da "síntese de influências estrangeiras na literatura nacional", bem como a compreensão de que a cultura brasileira resulta de uma soma de culturas diversas, não é exceção no romantismo, como se observa em "Literatura e civilização em Portugal", de Álvares de Azevedo, e em "Orgia dos duendes", de Bernardo Guimarães.

Em uma de suas "Memorabilia" e no primeiro verso de O Guesa, empregando as frases "Ser absolutamente eu livre" e "Eia, imaginação divina!", Sousândrade radicaliza o preceito romântico de que a arte, fruto de um "gênio inato", ordena-se de acordo com o sentimento e a imaginação de seu autor. Para dar corpo ao pressuposto, apoia-se na peculiar interpretação que os românticos fizeram da Crítica da faculdade do juízo, de Kant. Na recepção, determinam que o sujeito só é livre no reino da arte, exercendo com autonomia a sua faculdade estética de julgar, quando a imaginação e a razão agem com fim em si, sem conceito nem a coerção lógica do entendimento, reinos da ciência.

A proposição de que o juízo estético provoca um livre e desinteressado jogo com a forma e uma harmonia, ou um conflito, entre imaginação, entendimento e razão, impelindo à reflexão, leva Sousândrade a compor o seu poema como uma "tempestade de ideias". Em O Guesa, abundam sintagmas referentes ao campo semântico de "ver", modelando a enunciação como exercício contemplativo: "Vede além", "Tudo estou vendo", "Vê-se-lhe a imagem", "Ver eu creio...!", "Eu vi na terra", "Bom foi que eu visse!" etc. O poema se molda de acordo com a contemplação dos quadros da história, da natureza, das obras de arte favoritas do autor e de um material cujas metáforas fecham a analogia. Valendo-se do deslocamento físico quer como ato, quer como modo de enunciação que confere mobilidade à narração, a obra romântica prevê, como se sabe, a absorção

25. Cf. HOBSBAWN. Nações e nacionalismo desde 1780. Programa, mito e realidade, p. 44.

26. LOBO. Épica e modernidade em Sousândrade, p. 14. 
das impressões e da reflexão sobre os lugares visitados, física ou imaginariamente. ${ }^{27}$ Torna, com isso, verossímil o preceito de que a arte pode produzir conhecimento, divagar por áreas distintas do saber e, com isso, fundir gêneros, discursos e estilos. Peregrinando por suas reflexões, o narrador de O Guesa espera, como diz, colocar a "alma em ação".

O devaneio monológico e a autocontemplação interior do narradorGuesa também se apropriam, a seu modo próprio, do legado do caminhante solitário de Rousseau que, reconhecendo a sua solidão absoluta e a animosidade de seu público, estranha tudo que lhe é externo, destinando a sua obra a si mesmo, e seus dias restantes a estudar a sua alma e "preparar com antecipação as contas que não tardarei a prestar sobre mim" . Ao se tomar por destinatário e tema de seu discurso, Rousseau desiste de persuadir o auditório externo, certo de que ele já se convencera de sua culpa. ${ }^{29}$ Mas ao distender o fluxo da linguagem pelo filtro da emoção, não deixa de assentar a ênfase de sua linguagem no páthos que pode assim comover e mover o auditório.

Sousândrade, por sua vez, retoma a prática da conversação íntima, fazendo o poema se desenrolar também como narrativa de autorrevelação e pseudobiografia que encenam o espetáculo da consciência do herói-poeta em exercício de meditação, nos momentos em que procura assinalar a sucessão e a descontinuidade das impressões da vida interior e exterior que tocam a sua alma, sem deixar de dramatizar, em outros momentos, a autoridade unívoca de quem, situando-se do alto da história, espera convencer, por vezes imprecar em "platitudes derramadas", quanto à urgência de seu sistema ideológico.

Postulando o valor de qualidade da contemplação do "gênio", o poeta concebido por Sousândrade comunga, com Deus, do poder superior para estabelecer

27. "[...] o verossímil de Guesa é modelado pela ideia romântica de 'mudar de paisagem', que viveu: dispositivo de migração externa, é correlativo objetivo nem sempre congruente que figura a migração contínua dos sentimentos da 'paisagem interior' de seu herói, espécie de Childe Harold selvagem, sem limites, numa muito insatisfação voluptuosa dos limites que, por ser cambiante e indefinida sempre, é adequada à ironia titânica ou às metáforas do ideal dos seus conteúdos". HANSEN. Etiqueta, invenção e rodapé, texto inédito.

28. rousseau. Os devaneios do caminhante solitário, p. 12.

29. STAROBINSKI. Jean-Jacques Rousseau, a transparência e o obstáculo, p. 477. 
contato com potências cósmicas ou mediar a relação dos mortais com o conhecimento do mundo vário:

"Sente-se, vê-se na immortalidade

Dons, que da terra e já de nós s'ergueram:

De lá descendo a eterna claridade

Aos mundos animar, que esses the deram.

"De lá descendo o Creador ao mundo

D’aqui subindo a creação aos céus $(\ldots)^{30}$

No poema, a capacidade humana de apreender a síntese da vida múltipla perdeu-se com a queda do paraíso indígena originário, mas pode ser esteticamente reconquistada. Nessa negação acompanhada de idealização, outra queridíssima amante de Guesa pode contribuir para que ele exerça a divina potência de sintetizar o todo. Se Virjanura encarna o ideal de uma vida harmônica, Coelus, a deusa do Sol e mãe da Terra, concretiza-o.

No oitavo canto, de volta de sua experiência da África, Guesa desembarca na Ilha do Sol, uma fusão da ilha de São Luís com o sempre-Éden sousandradino. A cena se situa em um período posterior à opressão do povo americano empreendida desde a chegada das naus europeias, já num momento paralelo à existência dos "homens do mundo frívolo" que honram o "falso ídolo" do ouro. Musa da zona equatorial e última sobrevivente da tradição natal, Coelus proporciona o silêncio solitário da zona tórrida, uma profunda calma distante de qualquer agitação externa ou interna e a internalização da luz do dia. Amando sem nada pedir, reina em um mundo que prescinde do trabalho e favorece o gozo constante. Sua sábia beatitude desconhece o sofrimento ou a alegria e aprende a rir só depois que "a social mentira veiu". 31 Mistério divino do princípio e fim do mundo, Coelus pode, desde o primeiro encontro, enxergar no interior de Guesa o "processo moral da natureza / Incolôres princípios, a existência / Absoluta da aquém e além belleza”. A seu lado, Guesa partilha o divino conhecimento dos deuses $^{32}$ e passa a deter a sabedoria da terra. Vivendo nesse eterno presente

30. SOUSÂNDRADE. O Guesa, canto IV, p. 101.

31. SOUSÂNDRADE. O Guesa, canto VIII, p. 176.

32. SOUSÂNDRADE. O Guesa, canto VIII, p. 167. 
encantado, ele se vê, assim, numa atemporalidade que faz "esvaecer os echos confusos do passado" ${ }^{33}$ e apagar a urgência da memória.

A multiplicidade formal e temática de O Guesa resulta na forma inacabada, aberta ao infinito. Com isso, Sousândrade insere o seu poema no interior do histórico processo de criação de Fausto, de Goethe, escrito e rescrito ao longo da vida do autor. Assim constituído, O Guesa implica um excesso que atropela assuntos, gêneros e subgêneros.

Nesse sentido, a evocação de Gonçalves Dias no canto IV realiza-se na imagem de sua figura boiando nas ondas marítimas: "O oceano trazia-o com o egoísmo / De quem lhe havia de cantar a morte". Mas o naufrágio que vitimou Gonçalves Dia ocorreu em 1864, e a composição do canto em 1858. Ao publicar o poema com a divergência entre as datas, Sousândrade expõe as suas distintas camadas de composição, assumindo sua adesão ao fragmento romântico cujo inacabamento não é necessariamente circunstancial, derivando ainda da expectativa de que a obra de arte resulte das experiências de vida do autor.

Ao fraturar a unidade e a simetria clássica, acumulando assuntos, estilos e gêneros, O Guesa torna-se polimórfico. Em sua variedade e mistura, empresta, por exemplo, recursos estilísticos do gótico castelo medieval para descrever a Quinta da Vitória, casa de Sousândrade e de Guesa, o que permite ao autor lamentar a decadência da sua e da família patriarcal. O poema sousandradino vale-se do épico, lírico e dramático; da parábola, idílio, hino, ode, elegia, encômio, lira amorosa, crônica de viagem e histórica, lenda, mito, auto e pseudobiografia etc.

Nesse sentido, o canto IV é motivado pela tópica do retorno do filho nada pródigo à terra natal e abre-se com uma rápida caracterização e síntese da biografia do protagonista. Para figurar a sua emoção diante do retorno ao Maranhão, Sousândrade adapta a romântica situação enunciativa em que a personagem, à maneira do Childe Harold, do D. Juan byroniano e de tantos outros, anota, enquanto se desloca num tropel acelerado, as impressões e a reflexão sobre o local, num estilo que funde ação, contemplação e emoção. A composição do canto (1858) deu-se após o retorno do autor ao Maranhão, vindo provavelmente do Rio de Janeiro. Encerrando o registro das lembranças da infância do herói, o canto segue com a ode em homenagem a Gonçalves Dias, descrito, ao lado do narrador e de Joaquim Serra, como a "mãe terrível da saudade", um dos gênios da "tempestade"

33. SOUSÂNDRADE. O Guesa, canto VIII, p. 167. 
a quem não custaria "alevantar os mares". ${ }^{34}$ No canto, a condensação e a insistência metafórica na imagem do temporal forjam aos poucos a alegoria da tempestade do ímpeto criativo do "gênio" maranhense. Em seguida, o narrador corta o louvor ao conterrâneo para descrever as impressões de Guesa com o cenário natural e social da região.

A passagem do registro encomiástico para a descrição do espaço realiza-se com esse inesperado desafio ao leitor: "O Guesa penetrou na antiga selva, / D'onde nunca devera ter saido. / Accompanhe-o quem o possa!" 35 A partir de então, registra-se a contemplação da geomorfologia e das condições climáticas da região, com Guesa observando-a como uma essência em que convivem paradoxalmente o encantamento das formas, volumes e cores naturais e o poder destrutivo de suas forças. Em seguida, o narrador dedica-se a rememorar os encontros amorosos do herói, não sem antes tagarelar a respeito da decência feminina. $O$ canto encerra-se com uma nova remissão a Gonçalves Dias e Joaquim Serra, lidos a partir de sua ligação com a cultura local. Na descontinuidade narrativa do canto, um episódio da vida do autor funde-se à biografia ficcional, que cede espaço às impressões e ao estranhamento da paisagem natural e social, à lira amorosa, à história do presente etc., sequências essas envoltas de devaneios.

A faculdade contemplativa do narrador-Guesa e a imaginação sousandradina põem-se em permanente migração pelo mundo e tempos afora, apresentando os espetáculos da história e da natureza não de modo épico, mas regulando-os insistentemente pelos sentidos, sentimento e reflexão do narrador e do herói. A história "ruge do coração do Guesa", filtrada, com riso e dor, por suas faculdades sensíveis e intelectivas. Em certa passagem, o narrador formula a compreensão, corrente no século XIX, de que a história dos vencidos não se molda pelo heroísmo épico. Em que pese o aproveitamento de procedimentos formais da epopeia clássica por O Guesa, Homero e Camões não podem existir em um "império odioso" construído à custa do leite da mãe preta e sem contar com a audácia guerreira de seus heróis e letrados desterrados na própria terra e na vida, carência maior que motiva o tema da saudade ao longo do poema:

34. SOUSÂNDRADE. O Guesa, canto IV, p. 99.

35. SOUSÂNDRADE. O Guesa, canto IV, p. 87. 
- E' Camões o passado, que se preza

Grandioso; a homereal grandiosidade

E' presente, é porvir, é a belleza

Da mulher-crença, do homem-divindade.

O Luso ensina à glória d'obendiencia

Do povo ao rei; nas frentes a seus rêis

Põe o Grego - é a acção, é a consciencia,

São as eternas, são as vivas leis.

Venham dizer os nobres do destêrro

E o José-Bonifácio, a dor ignota

Do americano deploravel êrro:

Do rei, antes viu-se elle o patriota,

Que da patria o não foi. Ou foi - mas, lenta

De transição, ahi degenera a idéa

Que morre em paz, ou surge por violenta

Crise e parece a emancipar-se estrea. ${ }^{36}$

Nessa compreensão, o épico é incompatível com a "dor ignota" dos "nobres desterrados" de uma nação cujo rei, carecendo de patriotismo, transforma a monarquia em regime permanente de transição, degenerando a ideia libertária.

O peregrinar de Guesa pelos povos e tempos decaídos contribui para formar a sua consciência como um anti-herói. Ele se molda pela incorporação da vida simples, humilde e sacrificada de Jesus Cristo; do suposto estado de inocência juvenil de um povo antes da mercantilização; da rebeldia titânica dos românticos; da revolta dos heróis nacionais de libertação; da maldição de Prometeu e Ahasverus etc. Nesse acúmulo de camadas sobre a sua consciência, o Guesa torna-se puro, meigo, amigo fiel, mas também vingativo vagabundo, indolente, perdulário, namorador inconstante, libertino, "escravo dos gozos" e de todas as mulheres de "meigo olhar". A satírica narrativa imaginária de suas viagens resulta em um híbrido estilístico que, encerrando um assunto convencionalmente trivial - como a vida sexual e amorosa, bem como o drama individual e familiar de um herói vencido -, trata-o numa linguagem solene. Se os abandonados da pátria tornam-se trágicos, os "feitos", na história oficial, das personalidades que invadiram, colonizaram ou constituíram o Brasil como nação independente tornam-se burlescos.

36. SOUSÂNDRADE. O Guesa, canto VI, p. 153. 
Seu olhar frui o quadro natural, histórico, mítico e lendário ou harmonicamente, pelo prazer experimentado diante do espetáculo do belo natural e artístico, ou, conflituosamente, de modo tragicômico, quando se trata de contemplar as contradições humanas. O Guesa vale-se ainda dos princípios empregados por Kant para descrever o sentimento sublime como um misto de prazer e dor diante de um objeto cuja grandeza é absoluta, sem termo de comparação, como a destruição de um povo. No poema, as violentas inversões na ordem linear dos termos do período e no interior de um único segmento frasal, a pouca coesão de frases e versos, o uso largo de contrastes, do paradoxo e da hipérbole são recursos do sublime romântico. O poema persegue ainda o "verso que menos canta", que permita uma concentração maior do pensamento e favoreça a homologia do ritmo áspero e tenso com os traços do herói "selvagem e rude" e com a gravidade trágica do assunto. Para representar os conflitos históricos como um objeto incognoscível e incomensurável, o autor maneja violentas contradições, recorrentemente produzindo oximoros que podem - como a "angelical candura luciferiana" de Guesa ou o "negrume-luz-esquecimento" de Coelus, entre tantos outros - esfarelar a substância do objeto representado. Com esses procedimentos, um romântico pretende elevar o pensamento, arrebatar a alma e expressar o doloroso sentimento de incompreensão diante dos violentos conflitos humanos e das adversidades do destino. Esse sentimento só se apazigua quando, gerando prazer, contrapõe-se-lhe a resistência do ideal.

Aumentando complexidade do poema, a determinação romântica de que as regras da obra de arte singular emanam da originalidade autoral, que cria livremente as suas próprias regras, não implica jogar fora toda a água do banho da tradição, ou negar a legitimidade de seus modelos eleitos. Ao se valer da metáfora da errância como estrutura de seu discurso e compor a sentimental e imaginária narrativa, Sousândrade conta com uma longa tradição constituída, entre outras, pela Viagem sentimental, de Laurence Sterne; o Childe Harold's Pilgrimage e o D. Juan, de Byron; o Ahasverus, de Edgar Quinet, que fundamenta a sua obra em outra lenda, a do judeu errante. Como em Quinet, Sousândrade cria uma forma aparentemente extravagante que condensa quadros e tempos distintos, também confluindo misticismo e historicismo, teogonia e cosmogonia. No Brasil, o modelo mais próximo do caráter imaginário da viagem de Guesa pela história do Brasil encontra-se na prosa poética Meditação, de Gonçalves Dias, e, de certa forma, nos poemas narrativos O poema do frade e o Conde Lopo, de Álvares de Azevedo, também modelados pela fragmentação romântica. Sousândrade aproveita ainda 
passagens da obra de seus queridos autores. Homero, Virgilio, Dante, Milton, Goethe, Byron, Edgar Quinet, Heine, Odorico Mendes, Joaquim Serra, Gonçalves Dias, entre outros, participam, de alguma forma, com motivos, cenas e personagens que Sousândrade recria na experiência de Guesa.

No século XIX, a contestação da autoridade da tradição levou, com efeito, a um progressivo desmoronamento de seu sistema fixo de valores. Considerando, no entanto, que "demiurgos não criam do nada", a absoluta arbitrariedade e a total originalidade artística resultariam na perda de laço entre a obra e a convenção e, assim, em sua pronta incomunicabilidade. Homero, Cervantes, Dante, Shakespeare, Milton etc. serão sempre românticos para um romântico, suas lições devem ser aproveitadas em uma solução artística livre e individual. No século romântico, a relação com os modelos consagrados não passa necessariamente por uma fiel obediência, mas pode também depender de um menor ou maior conflito, mediando-se quer pela estilização ou pela intensificação da revisão crítica. Desdobramento da querela entre Antigos e Modernos, a "modernidade" ou a arte "interessante", como queria Schlegel, inicia-se com o fascínio pelas construções críticas da tradição. A arte romântica não necessariamente descarta, mas pode criar um conflito com as convenções poéticas. A relação entre a obra singular e seu modelo ideal pode se realizar mediante uma segunda recriação com vistas a singularizá-lo, ou superá-lo de modo criticamente paródico. Imbuído do princípio, Sousândrade estabelece um diálogo com seus próprios procedimentos artísticos e com o de seus mestres, o que não antecipa a deglutição antropofágica, mas favoreceu que esta atualizasse um antigo preceito romântico.

\section{The Guesa's soul in action}

Abstract: In some passages, O Guesa uses the neoclassical verisimilitude system, adjusting the action of the protagonist to an obligation of good morality and decency. The poem also mobilizes the verisimilitude privileged in the nineteenth century, introducing particular truths that are distant of the current convention. The author also uses the maxim according to which the conduct of the characters can be regulated by a radical originality. Keywords: Verisimilitude, Convention, Originality.

37. HEINE. O conteúdo que um poema encarna. In: Heine, hein? Poeta dos contrários, p. 261 


$$
\text { Referências }
$$

AUERBACH. Mimesis. Trad. I. Villanueva y E. Imaz. México: Fondo de Cultura Económica, 1995.

BERLIN, Isaiah. Estudos sobre a humanidade. Uma antologia de ensaios. Trad. Rosaura Eichenberg. São Paulo: Companhia das Letras, 2002.

BOSI. Alfredo. Sob o signo de Cam. In: Dialética da colonização. São Paulo: Companhia das Letras, 1992, p. 246-272.

CHAGAS, Pinheiro. Literatura Brasileira. José de Alencar, apud Gonçalves Dias e a crítica portuguesa no século XIX. Lisboa: Faculdade de Letras da Universidade de Lisboa; Porto Alegre: Pontifícia Universidade Católica do Rio Grande do Sul, 2010, p. 138.

DIAS, Gonçalves. Obras poéticas. Ed. Manuel Bandeira. São Paulo: Companhia Editora Nacional, 1944.

DIAS, Gonçalves. Poesia completa. Rio de Janeiro: Aguilar, 1959.

CAMPOS, Augusto e Haroldo. Revisão de Sousândrade. São Paulo: Perspectiva, 2002.

CUCCAGNA, Claudio. A visão do ameríndio na obra de Sousândrade. São Paulo: Hucitec, 2004.

GENETTE, Gérard. Vraisemblance et motivation. In: Figures II. Paris: Éditions Du Seuil, 1969, p. 71-100.

HANSEN, João Adolfo. Etiqueta, invenção e rodapé. Texto inédito.

HEINE. Heine, hein? Poeta dos contrários. Trad. André Vallias. São Paulo: Editora Perspectiva / Goethe Institut, 2011.

HOBSBAWN, Eric. Nações e nacionalismo desde 1780. Programa, mito e realidade. São Paulo: Paz e Terra, 1991.

LOBO, Luiza. Épica e modernidade em Sousândrade. São Paulo / Rio de Janeiro: Presença / Edusp, 1986.

PEREIRA DA SILVA, apud SOUSÂNDRADE. Memorabilia. In: Poesia e prosa reunidas. WILLIAMS, Frederick G.; MORAES, Jomar. (Org.). São Luís: Edições AML, 2003.

ROUSSEAU, Jean-Jacques. Os devaneios do caminhante solitário. Porto Alegre: L\&PM Pocket, 2008.

SOUSÂNDRADE. Poesia e prosa reunidas. WILLIAMS, Frederick G.; MORAES, Jomar. (Org.). São Luís: Edições AML, 2003.

SOUSÂNDRADE. O Guesa. São Paulo: Selo Demônio Negro, 2009.

STAROBINSKI, Jean. Jean-Jacques Rousseau, a transparência e o obstáculo. Trad. Maria Lúcia Machado. São Paulo: Companhia de Bolso, 2011. 